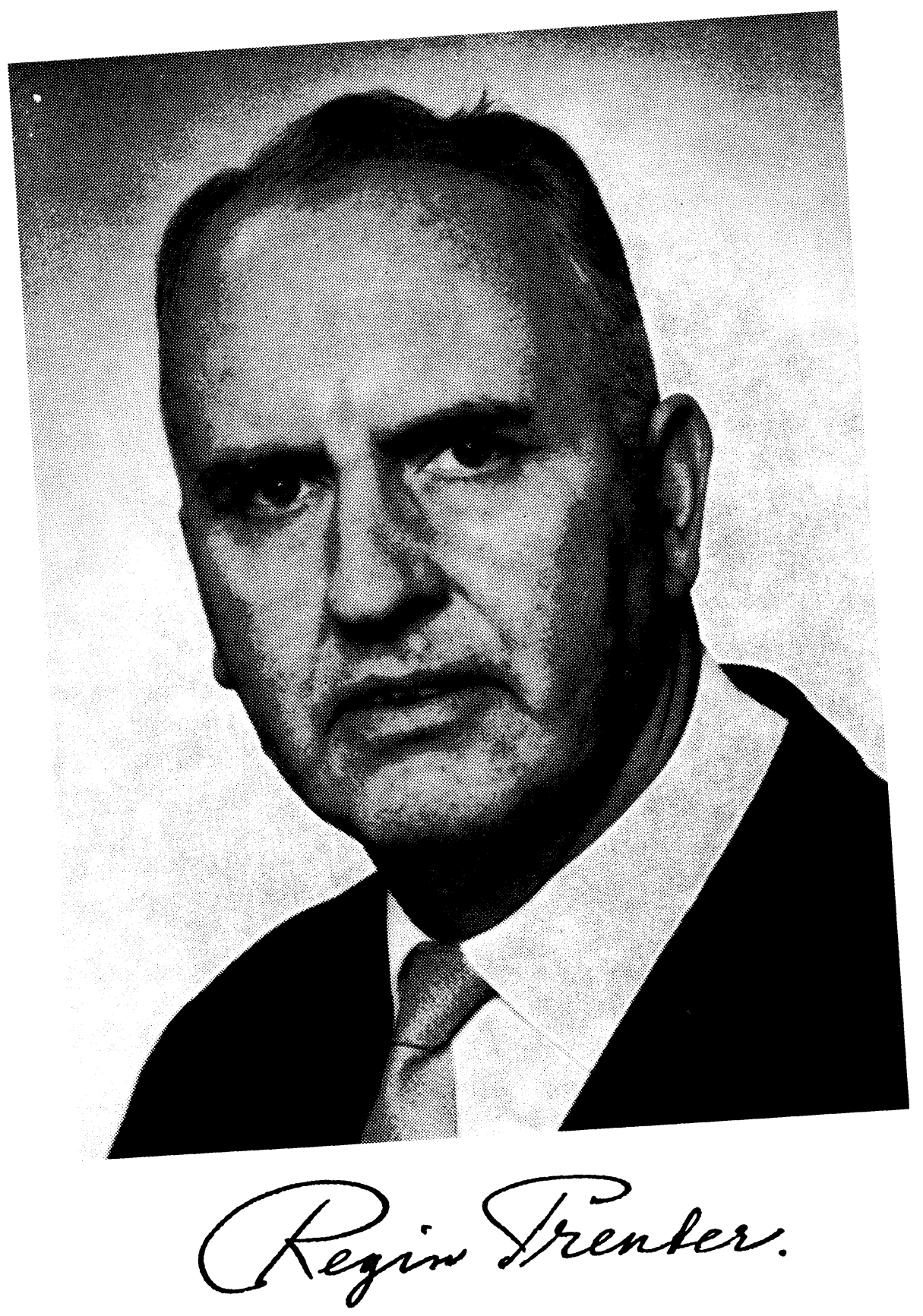




\section{Regin Prenter in memoriam}

\section{$6.11 .1907-15.12 .1990$}

Der er næppe mange, der i første række vil forbinde Regin Prenter med Grundtvig og grundtvigianisme. Prenter var kendt $i$ alle kredse, nød respekt og mødte hæder fra mange sider her $\mathrm{i}$ landet, og bestemt ikke mindre i det store udland; men han var først og fremmest kendt som Luther-forsker, som forfatter af den monumentale lærebog i dogmatik (oversat til flere fremmedsprog), og som deltager i debatten om aktuelle teologiske og kirkelige spørgsmål.

Når tankerne i forbindelse med hans mangesidige virke ikke umiddelbart falder på Grundtvig, hænger det antagelig desuden sammen med, at han - navnlig i sine senere år - lod sig knytte til den kirkepolitiske højrefløj. Således vil der formentlig være mange i den yngre generation, der alene forbinder Prenters navn med en stram, luthersk konfessionalisme, samt, i kirkepolitisk henseende, med en serie forbitrede angreb mod en påstået ensidig statskirkelig tendens i folkekirken. Prenter var den prominenteste modstander af kvindelige præster; men modstandergruppen reduceredes efter de første års skarpe konfrontation til et stadig mere trængt mindretal. I Prenters øjne var det imidlertid utåleligt, når flertallet uafladeligt med Grundtvig som forudsætning talte om den folkekirkelige åbenhed og frihed, om folkekirkeordningen som garanti for kirkeligt demokrati.

På denne baggrund kan der nok være anledning til at spørge, hvordan det forholder sig med Prenters egen Grundtvig-tolkning, og hvordan denne hænger sammen med de øvrige sider af det omfattende forfatterskab. Spørgsmålet kan også sættes på en mere direkte og provokerende formel: hvordan kunne det gå til, at en lærd og velfunderet kender af såvel Luther som moderne teologi, en så kulturåben, folkeligt bevidst personlighed som Prenter, til og med kosmopolit og $\emptyset$ kumenisk engageret, at just han blev bannerfører for den kirkelige højrefløj? Ja, at han trak i harnisk og placerede sit »gammelkirkelige « grundsyn, begrundet i Grundtvigs kirkelige anskuelse, særdeles synligt i banneret, når han vendte sig mod den $\mathrm{i}$ hans øjne forræderiske udviskning af kirkelig identitet, således som han så det udtrykt i administrationen af folkekirken? 
Lad det straks være sagt: der er al mulig grund til at tænke disse spørgsmål igennem mere end een gang, ikke blot for dermed at ære Prenters minde, som han kunne fortjene det, men fordi det aktuelt forekommer påtrængende nødvendigt at tage nogle sider af Prenters anliggende op som led i en kirkelig og teologisk statusopgørelse. Måske kunne Prenters skarpt optrukne standpunkter befordre en højere grad af sans for de grundliggende udfordringer, i stedet for at vi nok en gang forfalder til at søge en overkommelig kompromisløsning, alt imens vi skyder de principielle spørgsmål i baggrunden?

Følgende bidrag til et mindeportræt skal ikke foregive at præsentere et generelt billede af Prenters levnedsløb og forfatterskab. Derimod skal der peges på nogle sider af hans indsats som Grundtvig-forsker, eller rettere som kirkelig teolog i Grundtvigs ånd. Dette sker vel at mærke ud fra det synspunkt, at Prenters beskæftigelse med Grundtvig udgjorde langt mere end et sekundært hjørnefænomen i forhold til de måske umiddelbart mere iøjnefaldende hovedkomponenter i hans teologi: Luther-tolkningen og bidragene til en moderne systematisk teologi. Men det forekommer mig indlysende, at Prenters tolkning af Grundtvig hænger nøje sammen med hans sigte $\mathrm{i}$ de andre forbindelser. Med redegørelsen herfor vil der forhåbentlig kunne aftegne sig nogle overvejelser, der kan indgå i en bredere kritisk selvransagelse i aktuelt perspektiv.

I 1932 bestod Prenter den teologiske embedseksamen, sjældent glansfuldt. Det var åbenbart for lærerne ved det københavnske fakultet, at denne usædvanlige begavelse fortjente legatst $\varnothing$ tte til studieophold i Tyskland, Frankrig og England. Allerede $\mathrm{i}$ den tidlige fase af den store dannelsesrejse, under opholdet i Strasbourg, gav Prenter sig i kast med den systematiske teologi i hele dens bredde. Som den første dansker tog han Martin Heideggers værensfilosofi under grundig behandling, (jvf. artiklen »Martin Heideggers filosofi og teologien«, trykt i Theologisk Tidsskrift 1933, s. 161 ff.). Dette anføres her for at understrege den unge stipendiats alsidige talent, der altså også indbefattede religionsfilosofien.

Efter et længere ophold i Strasbourg samlede Prenters interesse sig om at komme til Bonn for at gennemføre studier hos Karl Barth. Denne var i begyndelsen af 1930'erne meget omtalt 
i Danmark og besøgte landet i marts 1933. Men Barths teologi blev næppe studeret grundigt af ret mange; snarere blev hans navn benyttet som et polemisk signal $\mathrm{i} \gg$ de unges « (d.v.s. Tidehvervs) opgør med »de æeldre (lederne i de kristne ungdomsorganisationer, O. Ricard, biskop V. Ammundsen og professor E. Geismar). Prenter havde imidlertid som en af de få blik for, at Barths betydning gik ud over, hvad der fremgik af dette meget lokale danske opgør, ja, at Barths »Kirchliche Dogmatik « (første bind udkommet 1932) repræsenterede et epokedannende nybrud.

Opholdet hos Barth i Bonn i årene 1933-34 skulle vise sig at blive særdeles betydningsfuldt for Prenters videre udvikling. Den positive inspiration fra Barth stod ganske åbenbart i forgrunden; Prenter imponeredes af Barths klare erkendelse af, hvilken alvorlig fare, der var for, at kirken skulle blive flyttet bort fra sin grundvold, hvis den lod sig løbe over ende af den nationalsocialisme, der i »Det tredje Riges« begyndelsesfase bølgede igennem Tyskland. Endnu vigtigere var det, at Prenter overbevistes af Barths principielle begrundelse for protesten mod den akut truende politisering af kristendommen: dogmatikken kan alene formuleres med udgangspunkt $\mathrm{i}$ den treenige Guds vidnesbyrd om sig selv, således som vi har dette bevidnet i Skrift og bekendelse. Den således begrundede kirkelige rettroenhed, fremholdt lige op i ansigtet på en aggressivt fremstormende massebevægelse, forblev utvivlsomt livsvarigt en afgørende indsigt for Prenter. Ikke desto mindre var der, sammen med denne tilslutning, fra begyndelsen også tale om et kritisk forbehold, idet Prenter på grundlag af Grundtvigs kirkelige anskuelse rettede spørgsmål til Barth. Det vidner om den 27-årige stipendiats intellektuelle kapacitet, om hans uforfærdethed og sproglige formåen, at han fremførte denne grundtvigsk inspirerede reservation i Barths seminar. Givetvis har Barth selv rystet rådvildt på hovedet efter at have påhørt Prenters indlæg; for mens Barth var fortrolig med Søren Kierkegaard, måtte den anden, fremmedartede, gådefulde, sakramentalt prægede danske teolog fra det 19. årh. vække undren. Prenters indlæg blev dog trykt i tidsskriftet »Evangelische Theologie « 1934, et af Bekendelseskirkens vigtigste talerør.

Efter opholdet i Tyskland gik rejsen videre til England, nærmere bestemt det anglikanske præsteseminarium i Lincoln, hvor Prenter modtog førstehåndsindtryk af den anglikanske kirke med 
dens vægtlægning på liturgi og det gudstjenestelige fromhedsliv. Under opholdet i 1935 var det fremfor alt samværet med Michael Ramsey, der førte Prenter videre i retning af en fordybelse i anglikansk ekklesiologi. Samtalen mellem disse to viste fremad i en grad, der umuligt kan have stået dem klart umiddelbart. Michael Ramsey blev teologisk professor, ærkebiskop i Canterbury og økumenisk forgrundsskikkelse. Hans netop i 1936 offentliggjorte bog »The Gospel and the Catholic Church « er et af anglikanismens moderne hovedværker. Desuden er Ramsey på engelsk grund en slags pendant til Karl Barth; i alt fald er Ramseys bog at betragte som en af de første kvalificerede replikker fra England til den barthske »åbenbaringsteologi«. Der er dog et vigtigt kritisk mellemværende mellem Ramsey og Barth, idet Ramsey for sit vedkommende i højere grad orienterer sig ud fra et kirkesyn i slægt med Grundtvigs (dog selvsagt uden at han på forhånd havde ringeste anelse om, hvem Grundtvig var), når han betoner, at teologien må tage udgangspunkt i den gudstjenestelige forkyndelse.

For Prenter blev disse indsigter aldeles afgørende. Gennem mødet med Ramsey på den ene side og Barth på den anden fik han en klar fornemmelse af det nutidige perspektiv, han ville anlægge på sine studier af Luther. Hermed var der kastet lys på den problemstilling, han gjorde til sit disputatsemne. Afhandlingen blev forelagt 1944 med titlen »Spiritus Creator. Studier i Luthers teologi«. Det er således uomtvisteligt, at Prenters teologiske projekt fra begyndelsen var forbundet med økumenisk vidde og internationalt udsyn. I centrum for den nutidige vurdering af Luthers helligåndsteologi stod Barths reformert farvede åbenbaringsteologi og Ramseys anglikanske gudstjenestelige teologi; samtidig var der et grundtvigsk inspireret grundsyn i Prenters vurderingsgrundlag.

Virkeliggørelen af dette ambitiøse forehavende måtte imidlertid foreløbigt stilles i bero, da Prenter ved sin hjemkomst i 1935 blev ordineret og indsat som sognepræst i Hvilsager-Lime på Djursland. I 1940 flyttede han til et embede som kapellan ved Aarhus Domkirke. Dette gav ham bedre adgang til at medvirke ved den teologiske undervisning ved det unge universitet $i$ byen, samtidig med at han i ledige stunder kunne hellige sig det fortsatte arbejde med disputatsen. I krigsårene lod Prenter sig des- 
uden drage med ind i den folkelige rejsning mod den tyske besættelsesmagt, endda så vidtgående, at han blev den hovedansvarlige for en teologisk udtalelse »Kirken og Retten« (1944), der må betragtes som besættelsesårenes mest gennemarbejdede teologiske dokument i Danmark. Tillige løste Prenter konkrete opgaver som modstandsmand.

Det bærende synspunkt i disputatsen er sammenhængen mellem åbenbarings- og kirkesyn, mellem Skrift og forkyndelse. Luthers syn på prædikenen kædes sammen med Grundtvigs betoning af det levende Ord i gudstjenesten. Prenter trækker en forbindelseslinie mellem Luthers gudstjenestesyn, samlet omkring Ordets tilsigelse i prædiken og sakrament (verbum vocale) og Grundtvigs betoning af de mundtlige tiltaleord og det sakramentale nærvær.

Ved Grundtvig-Selskabets stiftelse i 1947 indtrådte Prenter i styrelsen og forblev medlem indtil kort før sin $\mathrm{d} \varnothing \mathrm{d}$; han tog hyppigt del i forhandlingerne, såvel mundtligt som skriftligt. Således førte han disputatsens anliggende videre i en vigtig artikel fra Grundtvig-Studier 1948 »Grundtvigs syn på forkyndelsen«. Ja, den tætte sammenknytning af Luthers og Grundtvigs syn på forkyndelsen accentueres nu yderligere, således at samordningen af prædiken og sakramente hævdes at være gennemført med en højere grad af konsekvens hos Grundtvig end hos Luther.

»Grundtvig taler på en mere nuanceret måde end Luther om sakramentsordenes og forkyndelsesordets forskellige plads på den kristne livsvej. Det hænger sammen med, at han taler om Kristuslivet som et troens, håbets og kærlighedens liv på en anden måde end Luther«.

Ikke mindre betydningsfuldt er det, at Prenter benytter Grundtvigs gudstjenestelige teologi som grundlag for en i metodisk henseende helt central skelnen mellem forkyndelsens og det dogmatiske lærebegrebs væsen. Den netop omtalte samhørighed mellem forkyndelsen og det »nærvær og liv«, som menighedens tro og vished grunder sig på, føres nemlig videre til en skelnen mellem kirke og skole. I menighedens forsamling drejer det sig om troen, der hviler på Kristus-livet, hvorimod grundlaget for 
læremæssig klarhed hører hjemme i skolen og må anskues under »anskuelsens « fortegn. Heraf følger et prioriteringsforhold, således at gudstjenestens og troens uforanderlige fundament $\mathrm{i}$ »Klippekirken « rangerer på et andet og højere niveau end oplysning, granskning og skiftende udlægninger i »Friskolen«. I denne skelnen ser Prenter nøglen til en principiel bestemmelse af kirkens bundethed til dens grundvold set i forhold til teologiens frihed til i skolemæssig sammenhæng at lade den kritiske eftertanke komme til udfoldelse.

Dette grundsyn er en væsentlig faktor i et af Prenters hovedværker, lærebogen i dogmatik »Skabelse og Genløsning«. Som allerede titlen lader ane, er synet på menneskets skabthed, fald og genrejsning tydeligt farvet af Grundtvigs menneskesyn. Prenters inspiration fra Grundtvig er dog lige så udslagsgivende i fremstillingen af sakramenterne, hvilket allerede træder frem i overskrifterne. Dåben behandles under flg. temaangivelse: "genfødelsens bad« og nadveren omtales som »fuldendelsens offermåltid «.

Som professor ved det nystartede teologiske fakultet i Aarhus fra maj 1945 opbyggede Prenter talrige kontakter, hvoraf mange gik ud over landets grænser. Hans tetiske stringens og diskussionslyst sammen med sprogtalentet gjorde ham til en skattet gæsteforelæser og deltager $\mathrm{i}$ internationale konferencer og ved komitémøder. Det skal i den forbindelse noteres, at det føromtalte udgangspunkt, med Luther og Grundtvig som grundpiller, ikke stod $\mathrm{i}$ modsætning til den internationale orientering. Tværtimod var der for Prenter indre sammenhæng mellem det folkelige, dansk-nationale (når det vel at mærke blev tolket og forvaltet skønsomt) og det økumeniske perspektiv i den kirkelige anskuelse.

Prenter kom i årene efter krigen $\mathrm{i}$ et stadig skarpere optrukket modsætningsforhold til hovedstrømmen i dansk teologi og kirkepolitik. I historisk perspektiv er det nærliggende at sætte konflikten i forbindelse med den kendsgerning, at Prenter stillede sig i spidsen for modstanden mod kvindelige præster. Selv om der uomtvisteligt er tale om et væsentligt aspekt, ville det være en alt for snæver betragtningsmåde, hvis mellemværendet blev begrænset til striden om kvinders adgang til ordination. For Prenter selv var det åbenbart, at uenigheden havde bred og prin- 
cipiel karakter. Hvad der stod på spil, var for ham grundsandheder i bibelsk-reformatorisk kristendomsfortåelse; og i lyset heraf betragtede Prenter Grundtvig som eksponent for en "gammelkirkelig« holdning og dermed i modstrid med den brug, der blev gjort af ham i den moderne folkekirkelige tænkemåde.

I sådanne sammenhænge kunne den polemiske galde virkelig stige op i Prenter og få pulsen til at slå i hastig takt. Ifølge sit udgangspunkt betragtede Prenter sig som hørende til kirkens midte, men som følge af de anførte fronter måtte han henregne sig til det kirkelige mindretal (med denne karakteristik af situationen var der fra Prenters side rettet en fnysende sarkasme mod flertallet). For ham at se blev der kastet et helt og aldeles misvisende lys på debatten, når flertallet nøjedes med at vrænge ad »højkirkelighedens spøgelse« og i samme åndedrag tog patent på at forvalte de grundtvigske frihedstanker. I bogen »Protestantismen i vor tid « (1957) gik han ind på de principielle problemer angående forholdet mellem kirke og folk. Idet han selv søgte at videreføre grundsigtet bag Grundtvigs kirkelige anskuelse, vendte han sig harmfuldt mod det kirkepolitiske flertal:

»Var Grundtvig ikke den, der fremfor alt talte menighedens sag over for præstevælde? Var Grundtvig ikke den, der kæmpede for »jævnhed « imod al højkirkelig ceremonidyrkelse? Står Grundtvig derfor ikke, trods alt, et godt stykke til venstre for den protestantiske midte, vi i denne bog har prøvet at markere? Er Grundtvig f.eks. ikke adskilligt mere af en liberal protestant end denne bogs forfatter? - Det er ikke ualmindeligt blandt moderne grundtvigianere at besvare spørgsmål som disse bekræftende. Grundtvig tolkes i dag ofte mere som en slags liberal protestant end som dogmets forsvarer. Grundtvigs »kirkelige anskuelse « spiller i dag blandt yngre grundtvigske forkyndere ingen særlig rolle. Det, der i dag samler grundtvigianere i Danmark, f.eks. ved bispevalg, er visse kirkepolitiske synspunkter. Det ville derimod være ganske ugørligt at samle et større tal af grundtvigske mennesker omkring Grundtvigs kirkelige anskuelse i dens gammeldags form «.

Det er tydeligt, at Prenter gør inspirationen fra Grundtvig som klassisk, gudstjenestelig teolog til sit eget våbenskjold mod de 
moderne grundtvigianere, der har sat sig på flertallet i kirkepolitisk henseende og gør krav på at være de eneste, der har begreb om teologiens opgaver $\mathrm{i}$ en sækulariseret tidsalder. Men Prenter vil ikke affinde sig med, at kampen afgøres alene på grundlag af, hvilken part der finder flertal. Sagens kerne er af dogmatisk karakter, og kan man blot åbne kombattanternes øjne for dette som det egentlige anliggende, vil de få andet for end præstesager, fremfører Prenter i 1957.

Dette generelle opgør fik nogle år senere mere konkret karakter, da Prenter som bedømmer gik ind i en kritisk vurdering af Kaj Thanings vægtige disputats »Menneske først - Grundtvigs opgør med sig selv« (1963). Prenter lagde ikke skjul på, at der var tale om et imponerende arbejde, der indiskutabelt gjorde forfatteren fortjent til doktorgraden. Samtidig var Prenter imidlertid dybt uenig med afhandlingens hovedsynspunkt, Thanings hovedtese: at Grundtvig i 1832 nåede til vejs ende med et selvopgør, der førte ham til erkendelsen af det skabte livs egenværdi; »Menneske først» trådte fra 1832 i stedet for en pietistisk farvet »pilgrimsmyte«. Thanings tese var for Prenter at se udslag af en ensidig læsning af Grundtvigs omfattende tekstverden med dens talrige brydninger. Men i tillæg hertil så Prenter i Thanings påstand en afspejling af moderne sækulariseringsteologiske tankegange, der måtte føre til en uhistorisk, og i henseende til kristendomsforståelsen fatal fejllæsning. Prenter indvendte derfor mod Thaning:

»Grundtvig er - - på ingen måde en sækulariseringens profet. Når Thaning i sin Grundtvigtolkning mærkelig ensidigt viger tilbage fra at tale om vekselvirkningen mellem menneskeligt og kristeligt og kun vil tale om, at det menneskelige er en forudsætning for det kristelige, men er tilbøjelig til at stemple den anden side af vekselvirkningen, at det kristelige for folket er et middel til fremgang $i$ sand menneskelig udvikling og oplysning, som en inkonsekvens hos Grundtvig, har han åbenbart gjort Grundtvig mere moderne end han var. Men også denne ensidighed hænger sammen med, at gennembruddet $\mathrm{i} 1832$, når det kvalificeres som »omvendelse«, isoleres fra både en udvikling, der leder 
op til det, og fra den rolle, som denne forudsætning for gennembruddet bliver ved at spille også i den følgende tid «.

Prenter vil således ikke frakende Thaning en vis ret til at hævde betydningen af et nybrud hos Grundtvig i 1832, men han protesterer skarpt mod Thanings »mærkværdige blindhed for betydningen af det kirkelige gennembrud i $1825 \ll$. For Prenter var og blev det afgørende, at Grundtvigs kirkelige anskuelse bliver erkendt som det bærende grundlag gennem hele forfatterskabet, selv når man tager $\mathrm{i}$ betragtning, at der inden for dette helhedssyn findes accentforskydninger. Med en for Prenter karakteristisk harme og indignation på den teologiske sags vegne slynger han derfor følgende antitese tilbage imod Thaning:

\begin{abstract}
»Uden opdagelsen af kirkens urokkelige kendsgerning $\mathrm{i}$ 1825 ville Grundtvig aldrig, om han så havde mødt en hel række af yndige kvinder i England og hørt nok så mange maskinhjul snurre, være nået til at få brudt definitivt med sin romantiske misfornøjelse med nutiden på det folkelige område. Man spærrer sig selv vejen til forståelsen af dette menneskelige og folkelige gennembrud ved, drevet af ideen om en 'omvendelse' i.1832, at sønderrive forbindelsen mellem 1825 og 1832«. (Dansk teol. Tidsskr. 1964, s. 203).
\end{abstract}

Det mest vidtrækkende opgør med nutidige tendenser inden for dansk teologi og kirkeliv gennemførte Prenter i midten af 1960'erne. Få år forinden (1964) var han trådt frem for den kirkelige offentlighed som medunderskriver af en bekendelseserklæring »Kirkens ja og nej«, der med front mod dominerende tendenser i samtiden ville mane til respekt for Bibel og bekendelse. Dette engagement på den kirkelige højrefløj gav Prenter detaljeret begrundelse for i bogen »Kirkens embede. Udkast til en det kirkelige embedes dogmatik med luthersk udgangspunkt « (1965). Denne bog havde desuden baggrund i Prenters deltagelse i luthersk-anglikanske læresamtaler.

Det fortjener at blive fremhævet, at en monografi om det kirkelige embede $\mathrm{i}$ h $\varnothing \mathrm{j}$ grad udfyldte et tomrum, ja, det er fremdeles i dag således, at der ikke er leveret en sammenhængende, dogmatisk redegørelse for, hvordan kirkeretten principielt og den 
administrative praksis skal vurderes $\mathrm{i}$ forhold til den kirkelige ordning. Ganske vist er der $\mathrm{i}$ de seneste år, omsider, blevet opmærksomhed om kirkeretten som en hidtil overset udfordring også for danske teologer; men det sætter noget fundamentalt i den folkekirkelige tradition i relief, at det var Prenter, der med sine sympatier for den trængte højrefløj, fremlagde den mest gennemtænkte redegørelse for embedet, hvorimod flertallet lod sig slå til tåls med at henvise til administrativ praksis, den juridiske ekspertise og de almindelige samfundsvilkår.

Med angivelsen af dette perspektiv er der formentlig givet et fingerpeg om, hvorfor Prenter i bogen med så stor lidenskab insisterer på at beskrive det kirkelige embedes teologi og at gøre det med baggrund i kirkens gudstjeneste. Dette grundsyn vender han mod tendensen til at reducere embedet til en "praktisk indretning «, hvis varetagelse kan overvåges af politiske og administrative instanser som repræsentanter for statsmagten.

Det ville være på sin plads, om vi i dag, med den nyvakte opmærksomhed over for mange års forsømmelighed $\mathrm{i}$ forhold til disse perspektiver, tog Prenters arbejde frem til indgående behandling som led $\mathrm{i}$ en folkekirkelig principdebat, hvori synspunkter på Grundtvig og den grundtvigske arv måtte spille en central rolle.

Det er nemlig en kendsgerning, at Prenters arbejde ikke alene er kompetent og udfylder et tomrum, men også, at dets anliggende er langt mere betydningsfuldt end et negativt udfald fra den trængte højrefløj. Ganske vist er der også hos Prenter tale om en halsstarrig, konservativ inddragele af bibelteologiske sammenhænge og ræsonnementer ud fra den kirkelige tradition, uden at problemer i forhold til det moderne samfund eller de nutidige forståelsesvilkår tilsyneladende afficerer Prenter nævneværdigt. Men dette ændrer dog intet ved, at der fremføres velbegrundede og præcise angreb, f. eks. mod den udbredte »klerikalisme « $\mathrm{i}$ folkekirken. (NB! dette er kun eet blandt mange andre punkter, der godtgør, at det er uberettiget at marginalisere Prenters synspunkt). Skavankerne i folkekirken viser sig i Prenters øjne ved, at der i gudstjenesten er så ringe sans for lægfolkets medvirken. Den højkirkelige Prenter (!) protesterer harmfuldt mod tendenserne til præste- og embedsmandskirke, der blandt andet viser sig derved, at alle funktioner i kirken 
søges institutionaliseret. Dette har som en af sine fatale konsekvenser, at al interesse samler sig om at få funktionerne indpasset $\mathrm{i}$ det offentlige administrationsvæsen. Når derfor en stor del af opmærksomheden i den folkekirkelige debat beslaglægges af interesseorganisationernes højst pragmatiske ønsker, burde det i og for sig ikke komme bag på nogen, at der er så beskæmmende ringe interesse for det almindelige præstedømme som noget virkeligt i kirkens liv og tilsvarende for det særlige, kirkelige embedes teologi. Prenter accentuerer argumentationen yderligere ved at beklage ligegyldigheden over for embedets bekendelsesforpligtelse og enhver form for læretugt. Det turde være åbenbart, også nu 25 år senere, at der her er tale om en udfordring, der så langt fra alene angår højrefløjen.

Desuden må det fastholdes, at Prenter ikke er traditionalismens mørkemand. Han har f.eks. i høj grad blik for, at der ligger værdifulde muligheder gemt $\mathrm{i}$ den folkekirkelige rammelovgivning, herunder angående lægfolkets medvirken i menighedsrådene. Bogen er således mere end en pukken på det særlige embedes egenart; den rummer stedvis vigtige udspil og forslag til et samspil mellem præst og menighed:

»Den brydning mellem embedets væsen, som den dogmatiske analyse må se det, og embedets empiriske udformning, som den medbestemmes af en lang række ikke-kirkelige faktorer, har derfor ikke blot negative, men også i høj grad positive aspekter «.

I de her meddelte glimt fra det omfangsrige forfatterskab har mange væsentlige områder slet ikke fået den omtale, de kunne have fortjent, heller ikke når det er forudsat, at der alene skulle skrives om Prenters Grundtvigtolkning og dens konsekvenser. For dog at råde bod på et par af de mest graverende udeladelser skal det i det mindste lige anføres, at Prenter i forbindelse med Grundtvig-jubilæet i 1983 offentliggjorde nogle vigtige afhandlinger. Navnlig bogen »Den kirkelige anskuelse. En indførelse i N.F.S. Grundtvigs folkelige og kristelige grundtanker « (1983) fortjener opmærksomhed, fordi den er at betragte som en afrundet, pædagogisk og upolemisk sammenfatning af, hvordan Prenter tolker Grundtvigs kristendomssyn. Også den væsentlige 
artikel »Grundtvigs treenighedslære«, trykt i bogen »N.F.S. Grundvig. Theolog og Kirkelærer. Prædikener og foredrag fra 200-året.« Udg. af Konvent for Kirke og Theologi 1983, skal anføres.

Omtalen af disse publikationer fra den ældre Prenters hånd må imidlertid ikke forlede nogen til at antage, at han nu var blevet fredsommelig. Efter at have forladt universitetsgerningen i 1972 og være blevet sognepræst i Sønderjylland blev Prenter ved med at orientere sig alsidigt, publicere hyppigt og blande sig i diskussionen med lidenskab. Dette gav sig også i de seneste år udslag i endnu nogle skarpe ordvekslinger om Grundtvig-tolkningen. Især huskes en debat med Christian Thodberg om Grundtvigs nadverteologi (Præsteforeningens Blad, 1987), i hvilken Prenter - med eksplicit henvisning til den samtidige debat om liturgikommissionens forslag til fornyelse af de folkekirkelige ritualer - anklagede Thodberg for at give et misvisende billede af Grundtvigs sakramentsteologi. Og heri gemte der sig mere end eksegese af detaljer; Prenter påstod, at Thodberg med sine synspunkter banede vej for en »afsakramentalisering « af gudstjenesten. For en tredjepart kunne det nok volde vanskeligheder at komme til rettte med proportionerne, når Prenters galde $\mathrm{i}$ en sådan sammenhæng flød over; men tankekraften og evnen til at gribe fat om noget helt centralt dogmatisk svigtede aldrig.

Således var og blev Prenter en temperamentsfuld teolog, der drog i leding, når den nutidige udmøntning af Luther og Grundtvig gav anledning til opgør. Mindet om Prenters formidable forskningsindsats, herunder hans bestræbelse på at anskue dansk kirkelig tradition ud fra et internationalt, økumenisk perspektiv, æres bedst, hvis vi fastholder alle facetter af det modsætningsfyldte billede. Prenter var ofte over for fagkolleger den varmblodede stridsmand, men samtidig den kolossalt belæste og velorienterede, der elskede at diskutere og samtale. Han var kender af den teologihistoriske tradition, men samtidigt levende optaget af nutidige udfordringer. Over for det kirkelige lægfolk kunne han nok revse tidens forfaldstendenser, men han var samtidig den pædagogiske formidlings mester. Han var den indtrængende fortolker af Grundtvigs kirkelige anskuelse, men samtidig politisk engageret, passioneret kunst- og litteraturelsker. Han holdt af de bedste sider af dansk kultur og folkelighed, men var også den 
sprogbegavede verdensborger. Man må derfor spørge: kunne alt dette virkelig forenes i en og samme personlighed? Eller var der sider, der skurrede mod hinanden? Hvordan skal det vurderes, når Prenter insisterede på, at Grundtvig var »gammelkirkelig « og »førkritisk «, tilsyneladende uden at være anfægtet af teologiske modernitetsproblemer?

Disse og lignende spørgsmål vil blive stående; men de vil ikke fordunkle det centrale i billedet af Prenters indsats som forfatter af århundredets betydeligste lærebog i dogmatik og som den teolog, der byggede tolkningen af Grundtvigs kirkelige anskuelse ind $\mathrm{i}$ en systematisk-teologisk helhedsforståelse.

Jens Holger Schjørring 